\title{
An Assessment of the Relationship Between Peri-Implant Status and Dental Anxiety and Oral Health-Related Quality of Life
}

\author{
Çağrı Esen(0000-0002-4358-1293) ${ }^{\alpha}$, Ömer Ülker(0000-0001-6013-106X) ${ }^{\beta}$, Zekeriya Taşdemir(000-0003-0359-2462) ${ }^{\nu}$
}

Selcuk Dent J, 2021; 8: 508-515 (Doi: 10.15311/selcukdentj.794417)

Basvuru Tarihi: 13 Eylül 2020 Yayına Kabul Tarihi: 24 Şubat 2021

\section{ABSTRACT}

An Assessment of the Relationship Between Peri-Implant Status and Dental Anxiety and Oral Health-Related Quality of Life

Background: The purpose of this study is to evaluate the relationship between peri-implant diseases and dental anxiety and oral health-related quality of life.

Methods: In a total of 101 subjects (44 females, 57 males, mean age $56.9 \pm 12.1), 325$ implants were examined using modified plaque index, modified sulcus bleeding index, probing depth, bleeding on probing, clinical attachment level, suppuration, and keratinized mucosa width. The Oral Health Impact Profile (OHIP14) was used to measure the impact of oral health-related quality of life. For the purpose of assessing the dental anxiety level, Corah's Dental Anxiety Scale (DAS) was performed. In addition to dental implant measurements, the periodontal status of the participants' natural teeth was assessed by the Community Periodontal Index (CPI) of the World Health Organization.

Results: All created groups as peri-implantitis, peri-implant mucositis, and peri-implant healthy were compatible with each other in terms of gender, age, income level, smoking status, and oral hygiene practices $(p>0.05)$. A statistically significant correlation was found indicating that the peri-implant condition worsened as the education level decreased $(p=0.033)$. There was no statistically significant difference between study groups in terms of DAS, OHIP-14, and CPI. There was a significant correlation between the scores of DAS and OHIP-14 $(p<0.001)$.

Conclusion: No relationship was found between peri-implant diseases and dental anxiety and quality of life. It was determined that as the anxiety levels of the participants increased, their quality of life decreased.

\section{KEYWORDS}

Dental anxiety, Dental implants, Peri-implantitis, Quality of life

Both peri-implantitis and peri-implant mucositis are inflammatory diseases which may be seen around an osseointegrated implant. Peri-implant mucositis affects only the soft tissues surrounding the dental implant without an additional bone loss following osseointegration. ${ }^{1}$ If peri-implant mucositis left untreated, the disease extends into deeper tissues and turns into peri-implantitis. ${ }^{2}$ Peri-implantitis affects the supporting structures around an osseo-integrated implant and can lead to suppuration, alveolar bone loss, deep peri-

\section{ÖZ}

Peri-implant durum, dental anksiyete ve ağız sağlığıyla ilişkili yaşam kalitesi arasındaki ilişkinin değerlendirilmesi

Amaç: Bu çalışmanın amacı, peri-implant hastalıklar ile dental anksiyete ve ağız sağlığı ile ilişkili yaşam kalitesi arasındaki ilişkiyi değerlendirmektir.

Gereç ve Yöntemler: Toplam 101 katılımcıdaki (44 kadın, 57 erkek, ortalama yaş $56.9 \pm 12.1) 325$ implantta modifiye plak indeksi, modifiye sulkus kanama indeksi, sondalama derinliği, sondalamada kanama, klinik ataşman seviyesi, süpürasyon ve keratinize mukoza genişliği ölçümleri yapıldı. Ağız sağlığı ile ilişkili yaşam kalitesinin etkisini ölçmek için Ağız Sağlığı Etki Profili-14 (ASEP-14) kullanıldı. Dental anksiyete düzeyini değerlendirmek amacıyla Corah'ın Dental Anksiyete Skalası (DAS) uygulandı. Dental implant ölçümlerine ek olarak, katılımcıların doğal dişlerinin periodontal durumu, Dünya Sağlık Örgütü'nün Toplum Periodontal İndeksi (TPI) ile değerlendirildi.

Bulgular: Peri-implantit, peri-mukozit ve peri-implant sağlıklı olarak oluşturulan tüm gruplar, cinsiyet, yaş, gelir düzeyi, sigara içme durumu ve ağız hijyeni uygulamaları açısından birbirleriyle uyumluydu ( $p>0.05)$. Bununla birlikte, eğitim seviyesi düştükçe peri-implant durumunun kötüleştiğini gösteren istatistiksel olarak anlamlı bir korelasyon tespit edildi $(p=0,033)$. DAS, ASEP-14 ve TPi açısından çalışma grupları arasında istatistiksel olarak anlamlı bir fark yoktu. DAS ve ASEP-14 skorları arasında anlamlı bir korelasyon bulundu ( $p$ $<0.001)$.

Sonuç: Peri-implant hastalıkları ile dental anksiyete ve yaşam kalitesi arasında bir ilişki bulunmadı. Katılımcıların kaygı düzeyleri arttıkça yaşam kalitelerinin düştüğü belirlendi.

\section{ANAHTAR KELIMELER}

Dental anksiyete, Dental implantlar, Peri-implantit, Yaşam kalitesi

implant pocket, and finally the loss of the dental implant. $^{3}$ More dental implants inserted each day increase the incidence of future peri-implant diseases and raises interest in peri-implant disease etiologies and treatment options.

Peri-implant diseases and periodontal diseases have many common features in etiology, signs, and symptoms. Some common experiences of the patients due to peri-implant and periodontal diseases

\footnotetext{
${ }^{\alpha}$ Nevsehir Haci Bektas Veli University Faculty of Dentistry, Department of Periodontology, Nevşehir, Turkey

$\beta$ Nevsehir Haci Bektas Veli University Faculty of Dentistry, Department of Oral and Maxillofacial Surgery, Nevşehir, Turkey

${ }^{\gamma}$ Dentest Oral and Dental Health Polyclinic, Ankara, Turkey
} 
are: red, tender, and sometimes swollen mucosa, loss of supporting bone, bleeding and mild to moderate pain when brushing or chewing, bad breath, and aesthetic problems. Bacterial plaque is the most important etiological factor in peri-implant diseases as in periodontal diseases. ${ }^{4}$ Dental implants, like natural teeth, need brushing, flossing, and regular examinations by dentists.

Anxiety is a psychological disorder that can be described as an answer to an unknown danger. ${ }^{5}$ Dental anxiety is an advanced state of apprehension or fear felt towards dental treatments and instruments. ${ }^{6}$ Those who avoid dental treatments due to dental anxiety may lose their oral and dental health, which leads to feelings of lower general well-being and a lower quality of life. ${ }^{7}$ In response to the definition of health by World Health Organization's (WHO) in 1948 as "the absence of disease with a complete state of physical, mental, and social well-being", researchers have become more interested in the psychological and mental dimension. Oral health-related quality of life (OHRQoL) evaluates the comfort of the individuals while eating, sleeping, and engaging in social interaction and their self-esteem and satisfaction related to oral health. ${ }^{8}$ Although there are many studies reporting that there is a significant relationship between periodontal diseases and dental anxiety and OHRQoL, $6,9-17$ it is not clear whether this relationship also exists between peri-implant diseases and dental anxiety and OHRQoL. The aim of this study was to determine the relationship between peri-implant diseases and dental anxiety and OHRQoL by means of Corah's Dental Anxiety Scale (DAS) and a shortened 14-item questionnaire of Oral Health Impact Profile Index (OHIP-14).

\section{MATERIALS AND METHODS}

From the archives of a private dental polyclinic (Kayseri, Turkey) individuals whose dental implants were performed between 2012 and 2019 and whose prosthetic treatments were completed at least six months ago, were informed about this study on the phone. A total of 101 subjects with 325 implants mean age $56.96 \pm 12.14$ years (44 females, mean age: 55.23 $\pm 11.85 ; 57$ males, mean age: $58.30 \pm 12.30$ ) accepted to participate in this study and applied to the clinic for examinations.

After peri-implant measurements and periodontal evaluations were done, the patients completed a form to collect the OHIP-14 and DAS as well as socioeconomic and demographic data. The form also included questions on oral hygiene habits and smoking status. Participation was voluntary, and all subjects signed terms of informed consent. This study was approved by The Ethical Committee of Nevsehir Haci Bektas Veli University under process number 02.01.20/01.

\section{Peri-implant clinical measurements}

Clinical examinations were performed after removal of the supra-constructions by a single examiner (ÇE). Modified plaque index, ${ }^{18}$ modified sulcus bleeding index, ${ }^{18}$ probing depth, bleeding on probing and clinical attachment level were recorded at 6 sites (mesio-buccal, buccal, distobuccal, mesio-lingual, lingual, and disto-lingual) around each dental implant. Suppuration, after a slight pressure on the periimplant mucosa was noted as suppuration positive. The distance between the mucosal margin and the mucogingival junction was recorded as the keratinized mucosal width (KMW) at 6 sites (mesiobuccal, mid-buccal, disto-buccal, mesio-lingual, midlingual, and disto-lingual) of the mandibular implants and at 3 sites (mesio-buccal, mid-buccal, distobuccal) of the maxillary implants. All clinical data of dental implants were measured with a standard, intermittent, color-coded, plastic periodontal probe (Hawe Perio-Probe, Kerr, Bioggio, Switzerland) available in a scale $3 / 5 / 7 / 10$.

\section{Peri-implant case definitions}

The absence of inflammation (redness, swelling, bleeding on probing negative) and bone loss in the peri-implant tissues was diagnosed as peri-implant healthy. ${ }^{19}$ The presence of inflammation (redness, swelling, bleeding on probing) in the peri-implant mucosa without bone loss was diagnosed as periimplant mucositis. ${ }^{19}$ A probing depth of 6 millimeters and higher and a radiographic bone loss of 3 millimeters and higher was diagnosed as periimplantitis. ${ }^{19}$

\section{Study groups}

After the dental implants were diagnosed individually according to the peri-implant case definitions, the participants were distributed to the study groups. Participants having all implants diagnosed as periimplant healthy included in the peri-implant healthy group. Participants having one or more implants diagnosed as peri-mucositis and having no implants diagnosed as peri-implantitis included in the perimucositis group. Participants had one or more implants diagnosed as peri-implantitis included in the peri-implantitis group.

\section{Periodontal status evaluation}

Community Periodontal Index (CPI) has been recommended by $\mathrm{WHO}$ to assess the state of periodontal health. ${ }^{20}$ The particular categories of CPI were defined as: score 0 as periodontally healthy; score 1 as bleeding on probing; score 2 as calculus existence; score 3 as probing depth of 4 to 5 millimeters; score 4 as probing depth of 6 millimeters and deeper. After the examination of all teeth, the highest score was noted for each sextant. We used the mean value of a total of 6 scores of all sextants as 
CPI score to collect a piece of overall information on periodontal status in addition to peri-implant measurements. For calibration, the same observer (CE) performed all CPI measurements using a conventional manual periodontal probe (Kohler, Kohdent Medizintechnik, Stockach, Germany) with Williams markings.

\section{OHRQoL assessments}

Various OHRQoL instruments have been developed to date to evaluate the social impacts of oral and orofacial disorders on individuals' quality of life. ${ }^{21}$ Oral Health Impact Profile-14 (OHIP-14) has been commonly adopted as a shortened 14-item questionnaire from the 49-item version that offers a reliable instrument to predict the impact of oral health on the quality of life. ${ }^{21,22}$ OHIP-14 questionnaire contains handicap items between social disability and physical disability subscales. ${ }^{23}$ The results of a current study suggest that the shortened version of OHIP had good measurement properties when used to evaluate implant therapy outcomes. ${ }^{24}$ The 14 -item index includes a 5-point scale ranging from very negative (score 4) to very positive (score 0$)^{25}$ with a total score of 56 for each subject. We used the Turkish version of OHIP-14 questionnaire of which reliability, validity, repeatability, and intelligibility were proved in a previous study. ${ }^{26}$

\section{Dental anxiety assessments}

Corah's Dental Anxiety Scale (DAS), ${ }^{27}$ a widely used self-report instrument, is used to collect dental anxiety data in this study. DAS, the validity and reliability of which is widely accepted, ${ }^{28}$ has four questions, the answers range from 1 (no anxiety) to 5 (severe anxiety), $a=1, b=2, c=3, d=4$, and $e=5$, with a total possible score of 20 . We used the Turkish version of this scale of which validity and reliability were performed by a recent study. ${ }^{29}$

\section{Statistical analysis}

Kolmogorov-Smirnov test was used to test the normality of the data, whereas the Kruskal-Wallis and one-way ANOVA tests were used to analyze nonparametric and parametric data, respectively. Intergroup comparisons of categorical data were performed by the exact method of chi-square analysis. The relationships between parameters were evaluated by Pearson's correlation test. Data analysis was performed by using the software Statistical Package Version 22.0 (SPSS Inc., Chicago, IL, USA). The level of significance was set to $p<0.05$.

\section{RESULTS}

In this study, at the participant level; the frequency of peri-implantitis was \% 25.74, the frequency of peri-mucositis was $\% 80.20$ and the frequency of peri-implant healthy was $\% 47.53$. At the implant level; the frequency of peri-implantitis was $\% 12.92$; the frequency of peri-mucositis was \% 63.39; the frequency of peri-implant healthy was $\% 23.69$.

Of 101 subjects, only 29 had at least one type of systemic disease. These systemic diseases were diabetes mellitus (13 patients), hypertension (12 patients), heart disease (4 patients), asthma (1 patient), and goiter (1 patient). All participants with systemic diseases were under the control of a physician. There was no statistically significant difference in the distribution of patients who have at least one systemic disease to the study groups $(p=0.712)$. Also, there wasn't any statistically significant difference in the distribution of patients with diabetes mellitus, which is closely related to peri-implant and periodontal health, to the study groups $(p=0.511)$.

There wasn't any statistically significant difference among the groups in terms of age $(p=0.658)$, gender $(p=0.293)$, income per capita $(p=0.510)$, smoking status $(p=0.345)$, regular dental visits $(p=0.711)$, brushing frequency $(p=0.538)$ and the use of interdental agents $(p=0.590)$. However, a statistically significant correlation was found indicating that the peri-implant status worsened as the educational level decreases $(p=0.033)$ (Table $1)$. There wasn't any statistically significant difference among the groups in terms of OHIP-14 $(p=0.952)$, DAS $(p=0.728)$, and CPI $(p=0.078)$ scores (Table 2).

Regardless of study groups, correlation results of DAS and OHIP-14 and peri-implant clinical measurements (modified plaque index, modified sulcus bleeding index, probing depth, bleeding on probing, clinical attachment level, and KMW) are presented in Table 3. There was a significant correlation in terms of DAS and OHIP-14 scores $(p<0.001)$, and also between KMW and OHIP-14 scores $(p=0.042)($ Table 3$)$. 
Table 1.

Demographic and socio-economic characteristics, smoking status, and oral hygiene habits

\begin{tabular}{|c|c|c|c|c|}
\hline $\begin{array}{l}\text { Parameter } \\
\text { Variable }\end{array}$ & $\begin{array}{l}\text { Peri-implant } \\
\text { healthy group }\end{array}$ & $\begin{array}{l}\text { Peri-mucositis } \\
\text { group }\end{array}$ & $\begin{array}{l}\text { Peri-implantitis } \\
\text { group }\end{array}$ & $p$ value \\
\hline \multirow[t]{2}{*}{ Age } & 56.0 & 56.3 & 58.8 & 0.658 \\
\hline & $25-75$ & $24-82$ & $34-76$ & \\
\hline \multicolumn{5}{|l|}{ Gender } \\
\hline Female & 8 & 28 & 8 & 0.293 \\
\hline Male & 10 & 29 & 18 & \\
\hline \multicolumn{5}{|c|}{ Education level } \\
\hline Primary & 2 & 2 & 1 & $0.033^{*}$ \\
\hline Secondary & 4 & 22 & 9 & \\
\hline High & 2 & 9 & 11 & \\
\hline University & 10 & 24 & 5 & \\
\hline \multicolumn{5}{|c|}{ Income per capita } \\
\hline Low & 2 & 5 & 4 & 0.510 \\
\hline Medium & 9 & 23 & 14 & \\
\hline High & 7 & 29 & 8 & \\
\hline \multicolumn{5}{|c|}{ Smoking status } \\
\hline Smoker & 6 & 11 & 8 & 0.345 \\
\hline Non-smoker & 12 & 46 & 18 & \\
\hline \multicolumn{5}{|l|}{ Dental visit } \\
\hline $\begin{array}{l}\text { In case of } \\
\text { complaint }\end{array}$ & 17 & 55 & 24 & 0.711 \\
\hline Regular & 1 & 2 & 2 & \\
\hline \multicolumn{5}{|c|}{ Brushing frequency } \\
\hline Seldom & 4 & 20 & 11 & 0.538 \\
\hline Once a day & 8 & 27 & 10 & \\
\hline Twice a day & 6 & 10 & 5 & \\
\hline \multicolumn{5}{|c|}{ Interdental care } \\
\hline Exist & 7 & 15 & 8 & 0.590 \\
\hline Not exist & 11 & 42 & 18 & \\
\hline
\end{tabular}

Table 2.

Comparison of OHIP-14, DAS, and CPI scores among the study groups

\begin{tabular}{|lllll|}
\hline & $\begin{array}{l}\text { Peri-implant healthy } \\
\text { group }\end{array}$ & $\begin{array}{l}\text { Peri-mucositis } \\
\text { group }\end{array}$ & $\begin{array}{l}\text { Peri-implantitis } \\
\text { group }\end{array}$ & p value \\
\hline OHIP-14 & $7.11 \pm 5.79$ & $7.04 \pm 6.43$ & $7.0 \pm 5.36$ & 0.952 \\
\hline DAS & $8.22 \pm 3.61$ & $7.72 \pm 3.35$ & $7.46 \pm 2.08$ & 0.728 \\
\hline CPI & $1.73 \pm 0.59$ & $1.91 \pm 0.81$ & $2.42 \pm 0.7$ & 0.078 \\
\hline
\end{tabular}

OHIP-14: Oral Health Impact Profile, DAS: Corah's Dental Anxiety Scale, CPI: Community Periodontal Index
Table 3.

Correlation between OHIP-14 and DAS and periimplant clinical parameters

\begin{tabular}{|c|c|c|c|}
\hline Factor 1 & Factor 2 & $R$ & $p$ value \\
\hline OHIP-14 & DAS & 0.354 & $<0.001^{* *}$ \\
\hline MPI & OHIP-14 & 0.077 & 0.445 \\
\hline MPI & DAS & -0.27 & 0.786 \\
\hline MSBI & OHIP-14 & 0.037 & 0.716 \\
\hline MSBI & DAS & 0.158 & 0.114 \\
\hline PD & OHIP-14 & 0.075 & 0.457 \\
\hline PD & DAS & -0.08 & 0.429 \\
\hline BOP & OHIP-14 & 0.058 & 0.567 \\
\hline BOP & DAS & -0.037 & 0.712 \\
\hline CAL & OHIP-14 & 0.037 & 0.711 \\
\hline CAL & DAS & -0.044 & 0.659 \\
\hline KMW & OHIP-14 & 0.324 & $0.042^{*}$ \\
\hline KMW & DAS & 0.132 & 0.187 \\
\hline \multicolumn{4}{|c|}{$\begin{array}{l}\text { OHIP-14: Oral Health Impact Profile, DAS: Corah's Dental Anxiety Scale, KMW: Keratinized } \\
\text { Mucosal Width, MPI: Modified Plaque Index, MSBI: Modified Sulcus Bleeding Index, PD: } \\
\text { Probing Depth, BOP: Bleeding on Probing, and CAL: Clinical Attachment Level } \\
{ }^{*} p<0.05: \text { Statistically significant correlation between Factor } 1 \text { and } 2 \text {. } \\
{ }^{*} p<0.001 \text { Statistically significant correlation between Factor } 1 \text { and } 2 \text {. }\end{array}$} \\
\hline
\end{tabular}

\section{DISCUSSION}

Dental anxiety and oral health-related quality life are closely associated concepts. In response to this association, in a current study using DAS, McGrath \& Bedi $^{30}$ reported that people with high dental anxiety also had poor quality of life in Britain. In another research on the subject, patients with dental anxiety demonstrated the highest OHIP-14 scores, namely the worst OHRQoL. ${ }^{31}$ The difference between the mean OHIP-14 scores of the patients was dramatic as 22.4 in dental anxiety, 14.0 in temporomandibular disorders, and 4.1 in the general population. In accordance with these current studies, there was a strong correlation between OHIP-14 and DAS scores in our study. If all of these results are evaluated together, it can be said that reducing dental anxiety is an important factor in improving the quality of life.

There are a few studies that evaluated dental anxiety and OHRQoL together in patients with periodontal diseases and compared with controls. In one of these studies, Levin et al. ${ }^{6}$ stated that aggressive periodontitis occurred with statistically significant higher scores in DAS and lower scores in OHIP-14. A similar study, this time comparing chronic periodontitis patients with controls in terms of DAS and OHIP-14, notified that the patients in periodontitis group had high anxiety and worse OHIP-14 scores. ${ }^{14}$ Except for the studies which assessed dental anxiety and OHRQoL together with periodontal diseases, there are studies that evaluated periodontal diseases separately with OHRQoL and 
anxiety. In one of the studies on the relation of periodontitis and anxiety showed that periodontitis patients were not generally more anxious in terms of state-trait anxiety scale, they were scored significantly higher using DAS. ${ }^{32}$ In another study on the subject using the state-trait anxiety scale indicated the state anxiety levels as an important factor in the development of periodontal diseases. ${ }^{33}$ On the relationship between OHIP-14 and periodontal diseases, Jansson et al. ${ }^{13}$ demonstrated that patients who had more teeth with a bone loss of one third or more of the root length had a lower quality of life. Likewise, Araujo et al. ${ }^{17}$ stated higher OHIP-14 scores in chronic and aggressive periodontitis patients compared with gingivitis patients. In a recent study that used the new staging and grading classification of periodontal diseases, Karaaslan \& Dikilitas $^{16}$ noticed that OHIP-14 scores increased as the periodontal disease worsened with a statistical significance. Although several previous studies stated above reported relationships between periodontal diseases and anxiety and quality of life, we didn't find this relationship between peri-implant diseases and dental anxiety and OHRQoL in the limits of our study.

In a novel study that investigated the impact of periodontal disease on quality of life by means of OHIP14, it's reported that periodontal disease was associated with poor quality of life independent of socio-demographic parameters. ${ }^{12}$ Another novel study stated that OHIP-14 was associated with sex, age, and income and males OHIP-14 scores were higher than females with a statistical significance. ${ }^{17}$ In our study, in which we later distributed the participants from the whole study population to the groups, we did not find demographic and socioeconomic differences among the peri-implantitis, peri-mucositis, and peri-implant healthy groups.

When we examine the studies on OHIP-14, we can see that the average OHIP-14 values of the populations vary widely. For example, while in one of these studies ${ }^{16}$ the mean OHIP-14 value of patients who applied to the clinic for the treatment of periodontal diseases was 13.4, in another study ${ }^{25}$ this value was reported as 3.3 in subjects with dental implants in a control visit. It can be logical to say that the OHIP-14 values can change with the condition of the patients as healthy or sick at that moment. However, Alzarea ${ }^{23}$ notified that patients with dental implants are more satisfied with their OHRQoL. Compatible with this result, in our study population, the mean OHIP-14 score was $7.04 \pm 6.00$ out of a maximum of 56 , which shows the high satisfaction of the individuals with dental implants in a control visit.

While there are several studies in the literature evaluating the relationship between OHRQoL and dental anxiety and periodontal diseases, there are only few studies investigating the relationship between periimplant diseases and dental anxiety and OHRQoL. The studies on the relationship between dental implants and dental anxiety and OHRQoL generally don't focus on peri-implant status. One of these few studies which investigate the impacts of peri-implantitis on patient quality of life showed that the patients' quality of life worsened with the presence of periimplantitis due to higher levels of anxiety and lower satisfaction levels with implant treatment. ${ }^{34}$ From the results of another study that can provide information on this subject, an indirect relation between less radiographic bone loss and better quality of life can be established. ${ }^{35}$

A novel study in which plaque index, probing depth, bleeding on probing and clinical attachment level around dental implants and contra-lateral natural teeth as controls were measured, noticed that similar inflammatory conditions existed around both implants and natural teeth. ${ }^{23}$ We didn't find any significant differences between peri-implantitis, peri-mucositis, and peri-implant healthy groups in terms of CPI which reflects the periodontal status of the patients.

In a previous study, no statistically significant difference between smokers and non-smokers was notified when compared peri-implant bone loss. However, it's added that the trend towards more expressed bone loss in the smoking group. ${ }^{25} \mathrm{~A}$ current study reported that smokers treated with dental implants have a greater risk of developing

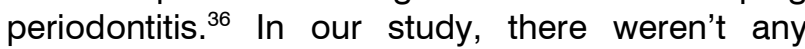
statistically significant differences among the groups in terms of smoking.

Clear criteria are currently available when diagnosing a dental implant as peri-implantitis, perimucositis, or peri-implant healthy as declared in the latest workshop. ${ }^{19}$ However, there is no classification describing the overall peri-implant status of a patient within our knowledge. Dental implants diagnosed as peri-implantitis, perimucositis, and peri-implant healthy can be present at the same time in a patient. While determining the groups in this study, we experienced the difficulty of being able to make the peri-implant diagnosis on the basis of implants, not on the basis of patients. As a model, we planned the groups as follows: those who have at least one dental implant diagnosed as peri-implantitis are in the periimplantitis group, those who have no dental implants diagnosed as peri-implantitis, but at least one implant diagnosed as peri-mucositis are in the peri-mucositis group and those who have all implants diagnosed as peri-implant healthy are in the peri-implant healthy group. However, future research may be beneficial in diagnosing not only the dental implants but also the patients in terms of peri-implant status. 


\section{CONCLUSION}

Within the limitations of the present study, no relationship was found between peri-implant diseases, and dental anxiety/quality of life. Furthermore, a significant correlation was found between dental anxiety scores and quality of life. 


\section{REFERENCES}

1. Acipinar S, Karsiyaka Hendek M, Olgun E, Kisa U. Evaluation of FGF-23 and 25(OH)D3 levels in periimplant sulcus fluid in peri-implant health and diseases. Clin Implant Dent Relat Res 2019;21:1106-1112.

2. Heitz-Mayfield LJ. Peri-implant diseases: diagnosis and risk indicators. J Clin Periodontol 2008;35:292-304.

3. Mombelli A, Lang NP. The diagnosis and treatment of peri-implantitis. Periodontol 2000 1998;17:63-76.

4. Lindhe J, Meyle J; Group D of European Workshop on Periodontology. Peri-implant diseases: Consensus Report of the Sixth European Workshop on Periodontology. J Clin Periodontol 2008;35:282-285.

5. Mills MP. Periodontal implications: anxiety. Ann Periodontol. 1996; 1: 358-389.

6. Levin L, Zini A, Levine J, Weiss M, Lev RA, Hai A, et al. Dental anxiety and oral health-related quality of life in aggressive periodontitis patients. Clin Oral Investig 2018;22:1411-1422.

7. Berggren U, Meynert G. Dental fear and avoidance: causes, symptoms, and consequences. J Am Dent Assoc 1984;109:247-251.

8. Sischo L, Broder HL. Oral health-related quality of life: what, why, how, and future implications. J Dent Res 2011;90:1264-1270.

9. Needleman I, McGrath C, Floyd P, Biddle A. Impact of oral health on the life quality of periodontal patients. $J$ Clin Periodontol 2004;31:454-457.

10. Ng SK, Leung WK. Oral health-related quality of life and periodontal status. Community Dent Oral Epidemiol 2006;34:114-122.

11.Cunha-Cruz J, Hujoel PP, Kressin NR. Oral healthrelated quality of life of periodontal patients. J Periodontal Res 2007;42:169-176.

12.Bernabé E, Marcenes W. Periodontal disease and quality of life in British adults. J Clin Periodontol 2010;37:968-972.

13. Jansson $H$, Wahlin $\AA$, Johansson $V$, Åkerman $S$, Lundegren N, Isberg PE, et al. Impact of periodontal disease experience on oral health-related quality of life. J Periodontol 2014;85:438-445.

14.Levin L, Zini A, Levine J, Weiss M, Lev R, Chebath Taub D, et al. Demographic profile, Oral Health Impact Profile and Dental Anxiety Scale in patients with chronic periodontitis: a case-control study. Int Dent J 2018;68:269-278.

15. Guentsch A, Stier C, Raschke GF, Peisker A, Fahmy MD, Kuepper H, Schueler I. Oral health and dental anxiety in a German practice-based sample. Clin Oral Investig 2017;21:1675-1680.

16. Karaaslan F, Dikilitas $A$. The association between stage-grade of periodontitis and sleep quality and oral health-related quality of life. $\mathrm{J}$ Periodontol 2019;90:1133-1141.

17.Araújo AC, Gusmão ES, Batista JE, Cimões R. Impact of periodontal disease on quality of life. Quintessence Int 2010;41:e111-e118.
18. Mombelli A, van Oosten MA, Schurch E Jr, Land NP. The microbiota associated with successful or failing osseointegrated titanium implants. Oral Microbiol Immunol 1987;2:145-151.

19. Renvert S, Persson GR, Pirih FQ, Camargo PM. Peri-implant health, peri-implant mucositis, and peri-implantitis: Case definitions and diagnostic considerations. J Periodontol 2018;89:S304S312.

20.Ainamo J, Barmes D, Beagrie G, Cutress $T$, Martin J, Sardo-Infirri J. Development of the World Health Organization (WHO) community periodontal index of treatment needs (CPITN). Int Dent J 1982;32:281-291.

21. Locker D, Matear D, Stephens M, Lawrence H, Payne B. Comparison of the GOHAl and OHIP-14 as measures of the oral health-related quality of life of the elderly. Community Dent Oral Epidemiol 2001;29:373-381.

22. Slade GD, Spencer AJ. Development and evaluation of the Oral Health Impact Profile. Community Dent Health 1994;11:3-11.

23. Alzarea BK. Assessment and Evaluation of Quality of Life (OHRQoL) of Patients with Dental Implants Using the Oral Health Impact Profile (OHIP-14) - A Clinical Study. J Clin Diagn Res 2016;10:ZC57-ZC60.

24. Allen $F$, Locker $D$. A modified short version of the oral health impact profile for assessing healthrelated quality of life in edentulous adults. Int $\mathrm{J}$ Prosthodont 2002;15:446-450.

25. Offord D, Mathieson G, Kingsford N, Matthys C, Glibert M, De Bruyn H. Peri-implant health, clinical outcome and patient-centred outcomes of implant-supported overdentures in the mandible and the maxilla. BDJ Open 2017;3:17017.

26. Basol ME, Karaagaçlioglu L, Yilmaz B. Developing a Turkish Oral Health Impact Profile OHIP-14-TR. Turkiye Klinikleri Dishekimligi Bilimleri Dergisi 2014;20:85.

27. Corah NL, Gale EN, Illig SJ. Assessment of a dental anxiety scale. J Am Dent Assoc 1978;97:816-819.

28. Sharma A, Pant R, Priyadarshi S, Agarwal N, Tripathi S, Chaudhary M. Cardiovascular Changes Due to Dental Anxiety During Local Anesthesia Injection for Extraction. J Maxillofac Oral Surg 2019;18:80-87.

29. Ilgüy D, llgüy M, Dinçer S, Bayirli G. Reliability and validity of the Modified Dental Anxiety Scale in Turkish patients. J Int Med Res 2005;33:252259.

30.McGrath C, Bedi R. The association between dental anxiety and oral health-related quality of life in Britain. Community Dent Oral Epidemiol 2004;32:67-72. 
31.Schierz O, John MT, Reissmann DR, Mehrstedt M, Szentpétery A. Comparison of perceived oral health in patients with temporomandibular disorders and dental anxiety using oral health-related quality of life profiles. Qual Life Res 2008;17:857-866.

32. Reisine ST, Fertig J, Weber J, Leder S. Impact of dental conditions on patients' quality of life. Community Dent Oral Epidemiol 1989;17:7-10.

33. Kesim S, Unalan D, Esen C, Ozturk A. The relationship between periodontal disease severity and state-trait anxiety level. J Pak Med Assoc 2012;62:1304-1308.

34. Insua A, Monje A, Wang HL, Inglehart M. PatientCentered Perspectives and Understanding of PeriImplantitis. J Periodontol 2017;88:1153-1162.

35. Sánchez-Siles M, Muñoz-Cámara D, Salazar-Sánchez $\mathrm{N}$, Ballester-Ferrandis JF, Camacho-Alonso $\mathrm{F}$. Incidence of peri-implantitis and oral quality of life in patients rehabilitated with implants with different neck designs: A 10-year retrospective study. J Craniomaxillofac Surg 2015;43:2168-2174.

36. Haas R, Haimböck W, Mailath G, Watzek G. The relationship of smoking on peri-implant tissue: a retrospective study. J Prosthet Dent 1996;76:592-596.

Corresponding Author:

Çağrı ESEN

Nevsehir Haci Bektas Veli University

Faculty of Dentistry

Department of Periodontology,

Nevşehir, Turkey

Phone : +90 5321718683

E-mail : cagriesen@hotmail.com 